\title{
Human Rights Protection in the EU as Unitas Multiplex
}

\author{
Noriko Ofuji
}

\section{Introduction}

Under the legal order of a State, rights set by law are guaranteed only to those who are qualified: the holders of nationality. That is to say, in the field of State law, the protection of human rights is assured under the sovereignty of Nation-States. According to this premise, holders of nationality are considered, if not the only, the primary ratione personae whose human rights are protected by the State. Through nationality, people are generally considered as socially subsumed to a specific State.

Therefore, those who possess foreign nationalities are not, in principle, considered to be the subjects of rights. The scope of ratione personae and the scope of ratione materiae of rights have been dependent upon the sovereign decisions of each State.

Indeed, as a result of remorse for the atrocities of the States during WWII, the "universal" nature of human rights has been emphasized since the end of the war, and human rights have been internationally guaranteed by treaties and conventions. However, these treaties and conventions only gain their legal binding force through acts of implementation by the States. Moreover, in the hierarchical structure of the legal order of the States, the validity of international treaties and conventions is very often considered to be inferior to Constitutional law. National courts frequently deny the "self-executing" nature of certain treaties, including those concerning human rights, and judge that they can only be effective through implementation by national legislation. Human rights guaranteed by treaties and conventions are thus restrained within the framework of the State legal order. In other words, the "universal" nature of human rights is dependent upon the active or passive protective measures of the sovereign States.

\footnotetext{
N. Ofuji $(\bowtie)$

Dokkyo University, Saitama, Japan

e-mail: ofuji@dokkyo.ac.jp

(C) The Author(s) 2018 
At the same time, however, sovereign rights of the States are no longer absolute or exclusive, as they were before. Ecological problems, for example, require global solutions, and refugee problems necessitate unified actions of the States, based on principles of humanity. The sovereign States often abstain from exercising their sovereign rights, accepting "supra-national" values and opting for peaceful coexistence with other States in an international context. Every state is in close coordination with other states, and state sovereignty, once considered to have an absolute and exclusive nature, is now seen more increasingly relative.

The traditional premise of the protection of human rights based on nationality is thus becoming less meaningful. It reflects the hierarchical relationship, within a sovereign State, between Constitution and treaties. However, in a situation where transborder movements and activities of people are not exceptional, the traditional way of protecting rights based on nationality may well cause difficulties.

The protection of human rights in the framework of the European Union (EU) law shows us a new way of protecting human rights, in the sense that the traditional static binary conflict between national Constitution and treaties in a State's legal order is dealt with "dynamically".

The Maastricht Treaty, signed in 1992 and put into force in 1993, first laid down the principles of EU citizenship, stipulating the possession of nationality of a Member State as a condition for its acquirement. By virtue of this notion, human rights, which were guaranteed in principle to the nationals within the framework of State legal order, are now guaranteed transnationally in the EU.

Below, I will present, first, the premises of EU law, which constitute the background of transnational human rights protection, and secondly, the relationship between a Member State's nationality and EU citizenship. Finally, I will cite a number of cases referred to the European Court of Justice concerning EU citizens who were placed in situations that made it difficult for them to exercise their rights. These situations arose either due to their having dual citizenship, or due to losing their nationality or national citizenship "placing them in a position capable of causing them to lose the status of the EU citizen"2 and the rights attaching thereto.

\section{Premises of EU Law}

\subsection{Unitas Multiplex}

EU is a polity that unites the Member States, with each State recognizing each other's differences and heterogeneity. In other words, the EU aims for unitas multiplex.

\footnotetext{
${ }^{1}$ See Bobbio (2012).

${ }^{2}$ Quotation from the Opinion of Advocate General (AG), Poiares Maduro, 30 September 2009 in Case C-135/08, Janko Rottmann v. Friestaat Bayern, at para 42.
} 
Article 2 of the Treaty on European Union (TEU) stipulates that the EU is a "multilateral" community "founded on the values of respect for human dignity, freedom, democracy, equality, the rule of law and respect for human rights, including the rights of persons belonging to minorities", and that these values are common to the Member States in a "society" in which "pluralism, non-discrimination, tolerance, justice, solidarity and equality between women and men prevail". This statement forms the basis for the assertion in the preamble of the Charter of Fundamental Rights of the EU that the EU "contributes to the preservation and to the development of ...common values while respecting the diversity of the cultures and traditions of the peoples of Europe as well as the national identities of the Member States".

The concept of unitas universalis is opposed to the concept of unitas multiplex. To assume that EU law is based on the concept of unitas universalis, is to place the EU in a superior position which transcends the sovereignty of the Member States: the EU will wield super-sovereignty over the Member States.

In contrast, unitas multiplex is a method of unification that seeks a "pluralistic solidarity", wherein each Member State reserves the right to its own sovereignty in relation to the EU as well as to other Member States. Member States will aim to unite as a whole, while at the same time remaining independent of each other. "United in diversity" is, in fact, the motto of the EU that first came into use in 2000. The Preamble to the TEU indicates that being "united in diversity" serves "to deepen the solidarity between their peoples while respecting their history, their culture and their traditions", and, according to the EU's official site, "it signifies how Europeans have come together, in the form of the EU, to work for peace and prosperity, while at the same time being enriched by the continent's many different cultures, traditions and languages". 3

While human rights are thus held to be a supreme value under the concept of unitas universalis, they are secured through mutual reference and coordination of protection by each Member State and the EU under the concept of unitas multiplex.

\footnotetext{
${ }^{3}$ https://europa.eu/european-union/about-eu/symbols/motto_en. This motto was clearly set out in Article I- 8 of the Constitutional Treaty, which did not come into effect because of the rejection of ratification by 2005 referendums in France and in the Netherlands. See Cohen-Jonathan and Dutheil de La Rochère (2003); Duprat (1996); Ruzié (1993), for example, regarding the EU law and the human rights in general. Concerning philosophical foundations of the EU law, see Dickson and Eleftheriadis (2012); Jaklic (2014). On unitas multiplex, see, for example, Prost (2013). Cf. Morin (1990) that states that Europe is a "complex" entity and any analysis of it must be based on the "Gordian knot" in which political, economic, social, cultural, religious and anti-religious histories are interwoven and interconnected in both conflicting and harmonious ways.
} 


\subsection{Core Principles of the EU: Principle of Non-discrimination on Grounds of Nationality (TFEU Art. 18) and Principle of Mutual Recognition}

EU aims to establish an "internal market", that is, "an area without internal frontiers in which the free movement of goods, persons, services and capital" is ensured (Article 26). In this market, the principle of non-discrimination on grounds of nationality plays an essential role, as people will be less inclined to trade across borders if there is a possibility that they will be discriminated against by the host Member State. Without this principle, freedom of movement between States would necessarily be hindered.

In this way, the principle of non-discrimination based on nationality confirms that goods, persons, services and capital of a Member State will be treated equally across borders, regardless of the State of origin or nationality. In other words, the purpose of the principle is to maintain the "compatibility" of the legal treatment of goods, persons, services and capital, and to ensure that the EU will be able to create a single market through its enforcement.

There are often cases where the regulatory measures of a State, applied to certain goods, persons, services and capital, differ from those of other States: for example, regulations for alcoholic beverages, or varying labor standards. The principle of mutual recognition is applied when the States implement their own legislative regulatory measures not only to their own products and workers, but also to foreign products and workers which are not subject to EU legislation, or to aspects of products falling outside the scope of such legislation.

Based on this principle of mutual recognition, Member States may not prohibit the sale of products or the employment of workers on its territory that are legal in other Member States, even when those products were manufactured or those workers were employed in accordance with technical rules different from those to which one Member State's domestic products and workers are subject.

Consequently, each Member State, in refraining from applying its own regulatory measures to other Member States' products and workers, thereby accepts the "difference" between its own regulations and those of other Member States. This principle enables the construction of a "loose" cooperative and confidential relationship among the Member States.

\section{Functions of Member States' Nationality and EU Citizenship}

Nationality is a legal tie that binds a person to a State. A person belongs to a specific state and holds its nationality. He or she acquires rights and assumes responsibilities that the legal norms of the State provide. 
In a modern State, under the principle of national sovereignty, nationality becomes a condition for acquiring citizenship, which entitles people to participate in a democratic system on which a "nation" is based. Following the adoption of universal suffrage, citizenship was given to all nationals without regard to property. Through citizenship, nationals form a legally and culturally unified community. ${ }^{4}$

What kind of people can then acquire nationality? That is to say, what conditions do people have to meet to acquire nationality? In the field of constitutional law as well as international law, these conditions are basically left to the discretion of the States. People who satisfy the requirements set by the State in the aim of helping them assimilate to the cultural norms of the State and accept its national identity, acquire nationality.

At the same time, States can deprive people of their nationality for specific reasons, so that they lose their rights and citizenship. Alternatively, States can deprive certain people of their rights and citizenship and yet let them keep their nationality. The concepts of nationality and citizenship can thus be used by the States to assimilate and accept people or exclude them.

\subsection{Conditions for Acquisition of EU Citizenship and the Rights One Holds as a Citizen}

EU is a body uniting the Member States, but it is not itself a State. Therefore, "a nationality of the EU" or "EU nationality" does not exist. Nor is the notion of EU citizenship tied to a particular EU nationality or to a particular people within the Union.

How, then, do people acquire citizenship without EU nationality? The Maastricht Treaty, which came into effect on 1993, defined "EU citizenship". Since then, EU Treaty states that "every person holding the nationality of a Member State shall be a citizen of the Union" (TFEU Article 20 (1), TEU Article 9). That is to say, EU citizenship is given on condition that people are nationals of one of the Member States. According to the European Court of Justice, EU citizenship "is destined to be the fundamental status of nationals of the Member States, enabling those who find themselves in the same situation to enjoy the same treatment in law irrespective of their nationality, subject to such exceptions as are expressly provided for". Thus, the Court confirms that, in any situation within the scope of ratione materiae of EU law, EU citizens can make use of the principle of nondiscrimination on grounds of nationality. ${ }^{5}$

Under the Treaty on the Functioning of the European Union (TFEU), EU citizens have "inter alia" (a) the right to move and reside freely within the territory of

\footnotetext{
${ }^{4}$ Duchesne (2007, pp. 71-81).

${ }^{5}$ Case C-184/99 Grzelczyk v. Centre public d'aide sociale d'Ottignies-Louvain-la-Neuve [2001] ECR I-6193, at paras 31-33. See also Case C-85/96 Martinez Sala [1998] ECR I-2691.
} 
the EU (Article 20 (2) (a), Article 21). This is an effect of the formation of the internal market. The Treaty Establishing the European Economic Community, enacted in 1958 (it was a predecessor of the Maastricht Treaty), had already assured workers' rights to move and reside freely within the internal market, but the Maastricht Treaty widened the scope of ratione personae concerning the rights to all the EU citizens. As mentioned above, in exercising the freedom to move and reside within the internal market, the right of an EU citizen to receive equal treatment in another Member State is also guaranteed through application of the principle of non-discrimination on grounds of nationality.

However, these rights are exercised in accordance with "the conditions and limits" defined by the Treaties and by the measures adopted thereunder [TFEU Article 20 (2)]. In principle, such freedom is assured only when EU citizens actually exercise their right to conduct transborder activities. ${ }^{6}$ In fact, in order that citizens have "the right of residence on the territory of another Member State for a period of longer than three months", they have to be "workers or self-employed persons in the host Member State". Or they must "have sufficient resources for themselves and their family members", and "have comprehensive sickness insurance cover in the host Member State" so as "not to become a burden on the social assistance system of the host Member State during their period of residence". 7

Furthermore, Member States are banned from expelling Union citizens who have resided in the host Member State for the previous ten years, unless such expulsion is based on grounds of national security, as defined by Member States. ${ }^{8}$

The EU citizens also have (1) the right to vote and to stand as candidates in elections to the European Parliament and in municipal elections in other States under the same conditions as nationals of these States (Article 20 (2) (b), Article 22). The principle of non-discrimination on grounds of nationality is equally applied to this right. ${ }^{9}$ (2) They have the right to enjoy, in the territory of a country in which their own State is not represented, the protection of the diplomatic and consular authorities of any Member State under the same conditions as the nationals of that state (Article 20 (2) (c), Article 23). (3) They also have the right to petition the European Parliament, to apply to the European Ombudsman, to address the institutions and advisory bodies of the Union in any of the Treaty languages, and to obtain a reply in the same language (Article 20 (2) (d), Article 24). ${ }^{10}$

\footnotetext{
${ }^{6}$ Article 3 (1) of the Directive 2004/38/EC of the European Parliament and of the Council of 29 April 2004 (on the right of citizens of the Union and their family members to move and reside freely within the territory of the Member States) affirms that "this Directive shall apply to all Union citizens who move to or reside in a Member State other than that of which they are a national, and to their family members defined in point 2 of Article 2 who accompany or join them".

${ }^{7}$ Article 7 (1) of the Directive 2004/38/EC.

${ }^{8}$ Article 28 (3) of the Directive 2004/38/EC.

${ }^{9}$ Cf. Case C-650/13 Delvigne v. Commune de Lesparre-Médoc [2015] ECR I-nyr, at para 43.

${ }^{10}$ These rights are also exercised in accordance with "the conditions and limits" defined by the Treaties and by the measures adopted thereunder [TFEU Article 20 (2)].
} 
As well as the above rights, the Lisbon Treaty, signed in 2007 and put into force in 2009, ensures that "not less than one million" EU citizens "who are nationals of a significant number of Member States" are provided with the right to "take initiative of inviting [the] European Commission, within the framework of its powers, to submit any appropriate proposal on matters where citizens consider that a legal act of the Union is required for the purpose of implementing the Treaties" [TEU Article 11 (4)], and that "in all its activities, the Union shall observe the principle of the equality of its citizens" (Article 9).

Under the Charter of Fundamental Rights of the European Union, signed in 2000 and given a legally binding effect by the Lisbon Treaty, "citizens" also have the right to good administration (Article 41) and the right of access to documents (Article 42). The provisions of the Charter including these rights are "addressed to the institutions and bodies of the Union with due regard for the principle of subsidiarity and to the Member States only when they are implementing Union law. They shall therefore respect the rights, observe the principles and promote the application thereof in accordance with their respective powers" [Article 51 (1)]. That is to say, "the fundamental rights guaranteed in the legal order of the European Union are applicable in all situations governed by European Union law", and therefore EU citizens can rely on any rights prescribed in the Charter opposed to contrary national legislation, as long as it "falls within the scope of European Union law". 11

\section{2 "Interstate Citizenship"}

EU citizenship does not belong to a single people. It opens up the political entity of each Member State to the citizens of other Member States, and gives them a specific legal and political status. In fact, the EU belongs to and is composed of citizens who do not share the same nationality. ${ }^{12}$ That is to say, the EU does not compel its citizens to have only one nationality or to be members of only one group: rather, it recognizes the unitas multiplex of different nationalities, of different peoples. ${ }^{13}$ It is based on "mutual commitment [of the Member States] to open their respective bodies politic to other European citizens and to construct a new form of civic and political allegiance on a European scale. It does not require the existence of a people, but is founded on the existence of a European political area from which

\footnotetext{
${ }^{11}$ Case C-617/10 ̊klagaren v. Hans $̊$ kerberg Fransson [2013] ECR I-nyr, at para 19. As regards EU citizenship and the rights of an EU citizen, see, for example, Fauvarque-Cosson, Pataut and Rochfeld (2011); Garot (1999); Konstadinides (2010); Wollenschläger (2011).

${ }^{12}$ Weiler (1999, p. 344).

${ }^{13}$ Opinion of Advocate General Poiares Maduro, 30 September 2009 in Case C-135/08, Janko Rottmann v. Friestaat Bayern, at para 23.
} 
rights and duties emerge". ${ }^{14}$ This is the "radically innovative character" of EU citizenship. ${ }^{15}$

In fact, EU citizenship is "citizenship beyond the state", an "interstate citizenship" 16 that enables citizens to exercise their freedom to move and reside within the internal market, to claim the right to be treated equally, and the right to vote and to stand as candidates in elections to the European Parliament and in municipal elections, etc. in Member States other than their own. It guarantees the legal status of EU citizen, to the nationals of the Member States, who have moved to another Member State other than their own.

In the EU, a political area in which pluralistic integration is realized through the political relationship among European citizens, EU citizenship functions as a notion that loosely integrates the "peoples of Europe".

\subsection{What It Means to Hold Nationality in a Member State}

The significance of holding nationality in a Member State of the EU, which was clarified by the opinion of the Advocate General Maduro in the European Court of Justice preliminary ruling in the Rottmann case (cited below), can be summarized as follows. ${ }^{17}$

(1) First, it means that EU citizens are involved in political relationships among themselves as well as in the "political area", where they are given not only citizenship of the State in which they hold their nationalities, but also a "new form of citizenship", which is the EU citizenship given "beyond the States".

(2) Second, the acquisition of EU citizenship does not negate citizenship in a State. Treaties state that EU citizenship "shall be additional to and do not replace the national citizenship" (TFEU Article 20 (1), TEU Article 9). EU citizenship is granted for the very reason that citizens hold nationalities of Member States. Therefore, EU citizenship may well strengthen the ties between the citizen and its Nation, but will not weaken it.

(3) Third, the status of "EU citizen" acquired by holding nationality in a Member State grants "a body of rights" not only to EU citizens themselves, but also by extension to their family members. Insofar as access to these rights are guaranteed "beyond the States", independently of the State, EU citizens are thus emancipated from their State of origin.

(4) Last, "the body of rights and obligations" associated with EU citizenship cannot be limited in an unjustified manner by the nationality of a Member State. That is to say, even though the acquisition and loss of nationality (and consequently

\footnotetext{
${ }^{14}$ Ibid.

${ }^{15}$ Ibid.

${ }^{16}$ Ibid., at para 16.

${ }^{17}$ Ibid., at para 23.
} 
of Union citizenship) is not in itself governed by EU law, "the conditions for the acquisition and loss of nationality must be compatible with" EU rules and "respect the rights of the European citizen".

\subsection{Acquisition and Loss of Nationality and the Discretion of Member States}

Under traditional international law, acquisition and loss of nationality has been left to the discretion of the States. According to the advisory opinion of the Permanent Court of International Justice expressed in 1923, concerning Nationality decrees issued in Tunis and Morocco, even though "the question whether a certain matter is or is not solely within the jurisdiction of a State is an essentially relative question" and "it depends upon the development of international relations". And yet, "in the present state of international law, questions of nationality are...in principle, within this reserved domain". ${ }^{18}$

Article 1 of the Convention on Certain Questions Relating to the Conflict of Nationality Laws concluded in 1930 that "it is for each State to determine under its own law who are its nationals" and that "this law shall be recognized by other States in so far as it is consistent with international conventions, international custom, and the principles of law generally recognized with regard to nationality". ${ }^{19}$ More recently, the European Convention on Nationality, introduced in the Council of Europe in 1997 and concluded in 2000, stated that "each State shall determine under its own law who are its nationals" (Art. 3, Sect. 1). ${ }^{20}$

Also, according to EU law, the conditions for acquisition and loss of nationality are, in principle, left to the competence of the Member States. Along with Declaration No. 2 on Nationality of a Member State, attached to the Maastricht Treaty, "wherever in the Treaty establishing the European Community reference is made to nationals of Member States, the question whether an individual possesses

\footnotetext{
${ }^{18}$ Advisory Opinion of Permanent International Court of Justice, 7 February 1923, on Nationality Decrees Issued in Tunis and Morocco, Series B No. 4 (1923), at para 40. See Sugihara (1972).

${ }^{19}$ Convention on Certain Questions relating to the Conflict of Nationality Laws, 12 April 1930, 179 L.N.T.S. 89 (LoN-4137), entered into force on 1 July 1937.

${ }^{20}$ Council of Europe, European Convention on Nationality, adopted on 6 November 1997, European Treaty Series 166. See Okuda and Tateda (2000, p. 1213). According to Article 2 (a) of the Convention, "'nationality' means the legal bond between a person and a State and does not indicate the person's ethnic origin". On the other hand, the International Court of Justice (ICJ) of the United Nations ruled on April 6, 1955 in Nottebohm Case (Liechtenstein v. Guatemala) (Second Phase), that "a State cannot claim that the rules it has laid down are entitled to recognition by another State unless it has acted in conformity with this general aim of making the nationality granted accord with an effective link between the State and the individual". This position of the ICJ is called the "genuine link" theory and, as will be explained below, it has not been adopted by the European Court of Justice. See Ruzié (1993, p. 109).
} 
the nationality of a Member State shall be settled solely by reference to the national law of the Member State concerned". ${ }^{21}$

However, as stated by the case law of the European Court of Justice, the competence of the Member States concerning granting and deprivation of nationality has been subject to certain restrictions based on the notion of EU citizenship.

\section{Cases of the European Court of Justice Concerning EU Citizens and Restrictions of the Discretionary Power of Member States}

\subsection{Member States Are not Allowed to Prefer One Nationality Over Another in a Case of Dual Nationality}

First, Member States are not allowed to prefer one nationality over another in a case of dual nationality. The European Court of Justice, in the 1992 Micheletti Case, judged that "under international law, it is for each Member State, having due regard to Community law, to lay down the conditions for the acquisition and loss of nationality. However, it is not permissible for the legislation of a Member State to restrict the effects of the grant of the nationality of another Member State by imposing an additional condition for recognition of that nationality with a view to the exercise of the fundamental freedoms provided for in the Treaty". ${ }^{22}$

Mr. Micheletti, who was born in Argentina of Italian parents, has since birth possessed both Argentine nationality by virtue of ius soli and Italian nationality by virtue of ius sanguinis. Mr. Micheletti applied for permission to establish himself definitively in Spain as a dentist, but he was denied this right by Spanish authorities. The freedom to move and to reside within the European Economic Community (predecessor of the EU) for the purpose of establishment of a business and the provision of services had already been given to nationals of the Member States. However, the Spanish authorities stated that, according to the Spanish Civil Code, for a person with dual nationality, the nationality corresponding to his or her last or actual residence is the nationality considered, and that therefore Mr. Micheletti must be regarded as an Argentine national rather than a Spanish national because, before he arrived in Spain, he had been residing in Argentina.

The European Court of Justice states that "the provisions of Community law on freedom of establishment preclude a Member State from denying a national of another Member State who possesses at the same time the nationality of a non-member country entitlement to that freedom on the ground that the law of the host State deems him to be a national of the non-member country". ${ }^{23}$ Such decision

\footnotetext{
${ }^{21}$ OJ 1992 C 191, p. 45.

${ }^{22}$ Case C-369/90 Micheletti and Others, 7 July 1992, [1992] ECR I-4239, at para 10.

${ }^{23}$ Ibid., at para 15.
} 
of a Member State will differentiate from one Member State to another, "the class of persons to whom the Community rules on freedom of establishment". 24

Advocate General Tesauro explains why the Spanish law was not acceptable in this case. He says that "if the argument were to prevail that only one nationality must always and invariably prevail, even for the purposes of Community law, it would follow - in the absence of unambiguous and uniform criteria common to all the Member States - that each case of dual nationality would be resolved differently in each Member State. The inevitable consequence of that situation would be that, on the basis of criteria which are in themselves lawful, there would be discrimination among different categories of nationals. Their eligibility or otherwise to share in the benefits conferred by Community law would depend on the internal provisions and/or criteria applied, for the purpose of resolving conflicts of nationality, by the State in which they intend to establish themselves, to the detriment of fundamental freedom guaranteed by the Treaty in the same manner to all the nationals of the Member States". 25

In short, a Member State may not apply other criteria (for instance, residence, as in Micheletti case) other than the possession of the Member State's nationality [Article 20 (1)], in order to prefer one nationality (of a non-member country) over another (Member State's nationality), in the case of dual nationality. It should be noted that the Court is not giving priority to EU citizenship over a difference in nationalities. But is, rather, in accordance with the core principles of EU law, prohibiting discrimination among EU citizens on grounds of nationality, and guaranteeing them the rights given through EU citizenship, after having moved from one Member State to another.

\subsection{Surnames as a "Format" of EU Citizenship}

In Garcia = Avello case of 2003, European Court of Justice stated that "although... the rules governing a person's surname are matters coming within the competence of the Member States, the latter must none the less, when exercising that competence, comply with Community law". ${ }^{26}$

This case concerned the change of the registered surname of two infants with dual nationality (Belgian and Spanish). The plaintiff in the case, the father of the two infants, acting as their legal representative, argued that the Articles of the Treaty prescribing the principle of non-discrimination on grounds of nationality and EU citizenship must be construed as precluding the administrative authority of a

\footnotetext{
${ }^{24}$ Ibid., at para 12.

${ }^{25}$ Opinion of Advocate General Tesauro, delivered on 30 January 1992, ECR I-4239. In relation to the Nottebohm case of the ICJ, cited above, under the EU law, the genuineness and the effectiveness of the nationality of the Member State will not be questioned in case of dual nationality.

${ }^{26}$ Case C-148/02, Garcia Avello [2003] ECR I-11613, at para 25.
} 
Member State from refusing to grant an application for a change of surname made on behalf of minor children resident in that State and holding dual nationality of that State and of another Member State. ${ }^{27}$

European Court of Justice held that it is not permissible to refuse to allow someone to change the surname of the children solely on the grounds that, in Belgium, the country of residence, "children who have Belgian nationality assume, in accordance with Belgian law, their father's surname". According to the Court, "a discrepancy in surnames is liable to cause serious inconvenience for those concerned at both professional and private levels resulting from, inter alia, difficulties benefiting, in one Member State of which they are nationals, from the legal effects of diplomas or documents drawn up in the surname recognized in another Member State of which they are also nationals". ${ }^{28}$ The European Court of Justice applied the non-discrimination principle on grounds of nationality, stating that "non-discrimination" requires not only "that comparable situations must not be treated differently", but also "that different situations must not be treated in the same way". 29

Furthermore, the Court quoted Micheletti case, saying that, "with a view to the exercise of the fundamental freedoms provided for in the Treaty", "it is not permissible for a Member State to restrict the effects of the grant of the nationality of another Member State by imposing an additional condition for recognition of that nationality". 30

Thus, in Garcia = Avello, which concerned holders of dual nationality, European Court of Justice, while admitting that the rules governing a person's surname are matters coming within the competence of the Member States, emphasized that Member States should definitely avoid a situation in which the discrepancy in surnames makes a person difficult to identify himself or herself and prevents him or her from exercising his or her rights as an EU citizen. A person's surname, therefore, functions here as a format that guarantees the rights based on EU citizenship.

This case demonstrates that, even though the matter concerning nationality was left to the discretion of the State, Member States are not allowed to restrict the possession of nationality of another Member State. In other words, what is important here is not the assurance of uniform protection of the rights of every EU citizen (beyond nationality), but the avoidance of placing an EU citizen in a discriminatory or differential situation in which he or she will not be able to enjoy rights that are conferred on nationals of other Member States.

\footnotetext{
${ }^{27}$ Ibid., at para 45.

${ }^{28}$ Ibid., at paras $36-38$.

${ }^{29}$ Ibid., at para 31 .

${ }^{30}$ Ibid., at para 28.
} 


\subsection{Nationality of a Member State Based on Ius Soli and EU Citizenship}

The relationship between EU citizenship and national legislation on immigration control should also be noted. In cases concerning a child of an immigrant or a refugee applicant born in one EU Member State who has become an EU citizen by acquiring the nationality of a Member State, European Court of Justice judged that not only the child, but also other family members who are caretakers of the child, should receive the right of residence. These are the cases involving acquisition of nationality by birth which occur in Member States adopting ius soli.

Zhu and Chen decision ${ }^{31}$ delivered in 2004 involves a woman of Chinese nationality (second appellant) who entered the United Kingdom (UK) but had given birth to her child (first appellant) in Ireland. As Ireland had adopted ius soli allowing any person born in Ireland to acquire Irish nationality, the child obtained Irish nationality. ${ }^{32}$ The mother and child, living in the UK, covered by health insurance and having sufficient resources, went to court because the UK refused to give them long-term residence: they claimed their right to permanent residence in the UK under EU law. European Court of Justice recognized the right to UK residence of the applicants, saying that "a refusal to allow the parent, whether a national of a Member State or a national of a non-member country, who is the carer of a child...to reside with that child in the host Member State would deprive the child's right of residence of any useful effect. It is clear that the child is entitled to be accompanied by the person who is his or her primary carer and accordingly that the carer must be in a position to reside with the child in the host Member State for the duration of such residence". 33

A similar case is Zambrano, ${ }^{34}$ held in 2008 , concerning a married couple of Columbian nationality who applied for refugee status in Belgium and gave birth to two children during the period of their application for asylum in Belgium. The two children obtained Belgian nationality under Belgian law, ${ }^{35}$ and subsequently became EU citizens. The father of the two children had been working illegally in Belgium, and, having had his employment contract canceled, he lodged an application for unemployment benefits. His application for these benefits having been

\footnotetext{
${ }^{31}$ Case C-200/02, Zhu and Chen [2004] ECR I-9925.

${ }^{32}$ According to then Irish law, a person born in Ireland is an Irish citizen from birth if he or she is not a citizen of any other country. The child in this case lost the right to acquire Chinese nationality by virtue of having been born in Northern Ireland and her subsequent acquisition of Irish nationality. See paras 9-13. However, by the Amendment of the Constitution Act, which was approved by referendum in 2004, the principle of automatic acquisition of Irish nationality by birth in Northern Ireland was abolished.

${ }^{33}$ Ibid., at para 45.

${ }^{34}$ Case C-34/09, Zambrano [2011] ECR I-1177. See Nakamura (2011, pp. 64-75).

${ }^{35}$ Columbian law did not recognize Colombian nationality for children born outside Colombia when the parents did not take specific steps to have them so recognized.
} 
rejected, he stated in the court that he should be able to enjoy the right of residence in Belgium as the parent of a minor child who was a national of a Member State in the EU, and that he should be exempt from the obligation to hold a work permit. ${ }^{36}$

The European Court of Justice judged that the expulsion of the parents of minor children (EU citizens), "would lead to a situation where those children...would have to leave the territory of the Union in order to accompany their parents." "Similarly, if a work permit were not granted" to such a parent, "he [or she] would risk not having sufficient resources to provide for himself and his family, which would also result in the children, citizens of the Union, having to leave the territory of the Union". It further averred that "Article 20 TFEU precludes national measures" such as the ones presented in this case, "which have the effect of depriving citizens of the Union of the genuine enjoyment of the substance of the rights conferred by virtue of their status as citizens of the Union". 37

In this manner, for immigrants or those seeking asylum, their rights to residence as the parents of an EU citizen who holds nationality in a Member State and whose nationality was based on the application of ius soli, are recognized, and the immigration control of the Member State concerned is restricted by EU law on the basis of the rights of EU citizens.

\section{4 "Due Regard to EU Law" and the "Principle of Proportionality"}

According to the European Court of Justice, even though the decision to withdraw the right of nationality is one of the competences of the Member States, as long as it falls within the scope of European Union law, the principle of non-discrimination on grounds of nationality must be applied, and Member States are obliged to "have due regard to European Union law" with the decision to withdraw naturalization being subject to the "principle of proportionality".

In Rottmann R $^{38}$ of 2010, the applicant, born in Austria, lost his Austrian nationality just after he had been given German nationality. During the time when the applicant was undergoing the procedures to become a naturalized citizen of Germany, he failed to mention the fact that he might lose his Austrian citizenship in an ongoing court case in Austria. Therefore, Freistaat Bayern (Germany) retracted his German citizenship retroactively, on the grounds that he had not disclosed the fact that he was the subject of judicial investigation in Austria and that he had, in consequence, obtained German nationality by deception.

In this case, the European Court of Justice held that, although the "matter falls within the competence of the Member States", "it is clear that the situation of a

\footnotetext{
${ }^{36}$ Ibid., at para 34.

${ }^{37}$ Ibid., at paras 42-45. See Nakamura (2012, pp. 135-157).

${ }^{38}$ Case C-135/08, Janko Rottmann v. Freistaat Bayern, [2010] ECR I-1449.
} 
citizen of the Union who...is faced with a decision withdrawing his naturalization, adopted by the authorities of one Member State, and placing him, after he has lost the nationality of another Member State that he originally possessed, in a position capable of causing him to lose the status conferred by [Article 20 TFEU] and the rights attaching thereto falls, by reason of its nature and its consequences, within the ambit of European Union law". 39 As a necessary condition for acquisition of EU citizenship is the possession of a Member State's nationality, losing the Austrian nationality as well as the German nationality meant that the applicant would also lose his status as an EU citizen.

According to the European Court of Justice, when Member States exercise "their powers in the sphere of nationality", they must "have due regard to European Union law". ${ }^{40}$ In the case of "a decision withdrawing naturalization", the decision must be governed by the "principle of proportionality". 41 That is to say, with regard to the loss of the rights of EU citizen, whether or not the measure taken by the Member State can be "justified" must take into consideration the following points: (1) "the consequences" of the decision withdrawing naturalization for the applicant and for the members of his family; (2) "the gravity of the offence" committed by the applicant; (3) "the lapse of time between the naturalization decision and the withdrawal decision"; (4) the possibility for the applicant to "recover his original nationality". 42

In addition, the Court states that "a Member State whose nationality has been acquired by deception cannot be considered bound...to refrain from withdrawing naturalization merely because the person concerned has not recovered the nationality of his Member State of origin". 43

Rottmann is hence an anomalous case in which European Court of Justice stated that the decision of the Member State to negate naturalization is not always bound to be reviewed by the Court even if the withdrawal of citizenship causes the applicant to become stateless.

\subsection{Restriction of a Member State's Decision of Deprivation of the Right to Vote in the Case of a Criminal Conviction}

The Delvigne case ${ }^{44}$ of 2015 concerns a Member State's decision to deprive a citizen of the right to vote.

\footnotetext{
${ }^{39}$ Ibid., at para 42.

${ }^{40}$ Ibid., at para 45.

${ }^{41}$ Ibid., at para 55.

${ }^{42}$ Ibid., at para 56.

${ }^{43}$ Ibid., at para 57.

${ }^{44}$ Case C-650/13 Delvigne v. Commune de Lesparre-Medoc [2015] ECR I-nyr, para. 43.
} 
France established a new Criminal Code in 1992, which provided that the total or partial deprivation of civil rights may not exceed 10 years in the case of a conviction for a serious offense. The applicant in this case was convicted of a serious crime and given a sentence of 12 years previous to the establishment of this new Code. The sentence also called for the permanent loss of the applicant's civil rights, so that he was deprived of his right to vote and of his right to run for office. The new Code repealed these provisions of the old Criminal Code, but only in cases of sentences passed after the new Code had been enacted, not retroactively. The applicant challenged the French court's decision, saying that, as he had been deprived of his rights to vote and stand for election in European Parliament (rights guaranteed under EU law as an EU citizen), ${ }^{45}$ the decision was contrary to the provisions of the Charter of Fundamental Rights of the European Union, Article 39. ${ }^{46}$

European Court of Justice stated that Article 39 (1) of the Charter "is confined to applying the principle of non-discrimination on grounds of nationality to the exercise of the right to vote in elections to the European Parliament," and thus "is not applicable to the situation at issue in the main proceedings, since... that situation concerns a Union citizen's right to vote in the Member State of which he is a national". ${ }^{47}$ It also stated that Article 39 (2) of the Charter, which "constitutes the expression in the Charter of the right of Union citizens to vote in elections to the European Parliament", shows that "it is clear that the deprivation of the right to vote" to which the applicant is subject under the provisions of the French legislation "represents a limitation of the exercise of the right guaranteed in Article 39 (2) of the Charter" ${ }^{48}$ Thus the limitations of the right imposed by the Article should fulfill the requirement that "the limitations are provided for by law, respect the essence of those rights and freedoms and, subject to the principle of proportionality, are necessary and genuinely meet objectives of general interest recognized by the EU or the need to protect the rights and freedoms of others". ${ }^{49}$ Concerning the French legislation at issue in the main proceedings, the European Court of Justice judged

\footnotetext{
${ }^{45}$ According to French Law No. 77-729 of 7 July 1977 concerning the election of representatives to the European Parliament (JORF, 8 July 1977, p. 3579), "the election of representatives to the European Parliament provided for by the Act annexed to the Decision of the Council of the European Communities of 20 September 1976...shall be governed by the [French] Electoral Code..." (Article 2).

${ }^{46}$ Besides rejecting the plaintiff's argument based on Article 39, the European Court of Justice also rejected his argument based on Article 49 (1) for the following reasons: "the rule of retroactive effect of the more lenient criminal law, contained in the last sentence of Article 49 (1) of the Charter, does not preclude [the French legislation]...since..., as amended, that legislation is limited to maintaining the deprivation of the right to vote resulting, by operation of law, from a criminal conviction only in respect of final convictions by judgment delivered at last instance under the old Criminal Code. In any event...that legislation expressly provides for the possibility of persons subject to such a ban applying for, and obtaining, the lifting of that ban". Case C-650/13 Delvigne, op. cit., at paras 56-57.

${ }^{47}$ Ibid., at paras 42 and 43 .

${ }^{48}$ Ibid., at paras 44 and 45 .

${ }^{49}$ Ibid., at para 46.
} 
that, since the limitation had the effect of "excluding certain persons, under specific conditions and on account of their conduct, from those entitled to vote in elections to the Parliament", it did not "call into question that right as such", "as long as those conditions are fulfilled". ${ }^{0}$ It then concluded that "a limitation such as that at issue in the main proceedings is proportionate in so far as it takes into account the nature and gravity of the criminal offence committed and the duration of the penalty". 51

From these preliminary rulings of European Court of Justice, it can be comprehended that, even though matters such as the conditions for acquisition and loss of nationality are basically left to the discretionary power of the Member States, those conditions must be correlated with rights given under EU law, insofar they are linked with rights assured through EU citizenship. In other words, the laws of the Member States concerning nationality cannot unreasonably restrict rights and obligations based on EU citizenship.

\section{Conclusion}

What is important in the context of EU law, is to assure a holder of nationality of a Member State, after having settled to another Member State, the enjoyment of the rights as an EU citizen.

Nationality under the legal system of a Member State functions as a tool of "identifying" people, designating the State to which they belong (function of identification), whereas under the EU law, nationality functions as an index that "differentiates" itself (one nationality) from another (function of differentiation).

Accordingly, in the EU, difference of nationalities reveals conflicts among legal treatments of various Member States. In order to avoid such conflicts, each Member State will have to change its own legal treatment to attain mutual "compatibility" among various treatments of the Member States. As mentioned above, it is the EU citizenship that makes such "compatibility" possible through rights assured therein and through principles of "non-discrimination on grounds of nationality" and "mutual recognition".

EU law guarantees human rights to EU citizens. They are not guaranteed by simply granting them "EU nationality", as each Member State does by virtue of its State sovereignty. Human rights under EU law are rather protected by referring both to the rights based on the nationalities of Member States and to the rights grounded in EU citizenship. Maintaining and developing "compatibility" between these two references is the basic task for both European Court of Justice and the Member State's courts: This reflects the dynamics of the EU law under the concept of unitas multiplex.

\footnotetext{
${ }^{50}$ Ibid., at para 48.

${ }^{51}$ Ibid., at para 50.
} 


\section{References}

Bobbio N (2012) De la structure à la fonction - Nouveaux essais de théorie du droit - (traduit et présenté par Soldini D). Dalloz, Paris

Cohen-Jonathan G, Dutheil de La Rochère J (eds) (2003) Constitution européenne, démocratie et droits de l'homme. Bruylant, Brussels

Dickson J, Eleftheriadis P (eds) (2012) Philosophical Foundations of European Union Law. Oxford University Press, Oxford

Duchesne S (2007) Citoyenneté, nationalité et vote: une association perturbée. Pouvoirs 120:71

Duprat G (ed) (1996) L'Union européenne -droit, politique, démocratie. Presses Universitaires de France, Paris

Fauvarque-Cosson B, Pataut E, Rochfeld J (eds) (2011) La citoyenneté européenne. Société de législation comparée, Paris

Garot MJ (1999) La citoyenneté de l'Union européenne. l'Harmattan, Paris

Jaklic K (2014) Constitutional pluralism in the EU. Oxford University Press, Oxford

Konstadinides T (2010) La Fraternité Européenne? The extent of national competence to condition the acquisition and loss of nationality from the Perspective of EU citizenship. Eur Law Rev $35: 401$

Morin E (1990) Penser l'Europe. Gallimar, Paris

Nakamura T (2011) Case C-34/09, Ruiz Zambrano v. Office national de l'emploi [2011] ECR I-01177; Case C 434/09, McCarthy v. Secretary of State for the Home Department [2011] ECR I-03375, Boeki to Kanzei (Trade and Customs) 59(10):75. (in Japanese)

Nakamura T (2012) The Current State of Union Citizenship Case Law: from Mobile Citizens' rights to resident citizens' rights? EU Stud Jpn 32:135. (in Japanese)

Okuda Y, Tateda A (2000) The 1997 European Convention on Nationality. Hokkaido Law Rev 50 (5):1213. (in Japanese)

Prost M (2013) Unitas multiplex. Unités et fragmentations en droit international. Bruylant, Brussels

Ruzié D (1993) Nationalité, effectivité et droit communautaire. Revue générale de droit international public 107

Sugihara T (1972) The development of the advisory function of the international court of justice (2). Hokkaido Law Rev 22(4):137. (in Japanese)

Weiler JHH (1999) The constitution of Europe. Cambridge University Press, Cambridge

Wollenschläger F (2011) A New Fundamental Freedom beyond market integration: union citizenship and Its dynamics for shifting the wconomic paradigm of European integration. Eur Law J 17(1):1

\section{Author Biography}

Noriko Ofuji is professor of Constitutional Law at Dokkyo University. Her main research issues are: 1. Compatibility/incompatibility between national and international legal orders, 2. Preservation of national identity in the context of trans-national/ global legal phenomena, 3. Development of 'human rights' in multi-legal context (esp. in European law field). Her research activities: Publications in French (selective list): La portée du principe d'égalité ou de non-discrimination dans l'ordre juridique japonais, in Mamiko Ueno (ed.) La métamorphose contemporaine du droit, des institutions et des droits, Chuo University Press, 2013; La démocratie au-delà de l'Etat, in Olivier Jouanjan, Alexandre Viala et Hajimé Yamamoto (eds.) VIIème Séminaire franco-japonais de droit public : les mutations contemporaines de la démocratie, Presses de Monéditeur.com, 2007; Du 'Gouvernement' à la 'Gouvernance' : Ce que signifie 
l'acquisition de la 'confiance, Hajimé Yamamoto \& Olivier Jouanjan (ed.) Action publique et globalisation, Annales de la Faculté de droit de Strasbourg, Nouvelle série, no. 8, 2006; 'La tradition constitutionnelle et la supra-constitutionnalité : y a-t-il une limite à la révision constitutionnelle ?' Revue française du droit constitutionnel, No. 59, 2004; 'Constitution, Loi et Traités internationaux, -Leurs statuts dans les systèmes juridiques français et japonais', Alexandre Viala (coordinated by), La Constitution et le temps, L'Hermès, 2003.

Open Access This chapter is licensed under the terms of the Creative Commons Attribution-NonCommercial-NoDerivatives 4.0 International License (http://creativecommons. org/licenses/by-nc-nd/4.0/), which permits any noncommercial use, sharing, distribution and reproduction in any medium or format, as long as you give appropriate credit to the original author (s) and the source, provide a link to the Creative Commons license and indicate if you modified the licensed material. You do not have permission under this license to share adapted material derived from this chapter or parts of it.

The images or other third party material in this chapter are included in the chapter's Creative Commons license, unless indicated otherwise in a credit line to the material. If material is not included in the chapter's Creative Commons license and your intended use is not permitted by statutory regulation or exceeds the permitted use, you will need to obtain permission directly from the copyright holder.

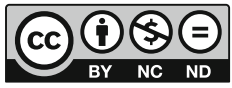

